\title{
6. Probing the power of entrepreneurship discourse: an immanent critique Pascal Dey
}

[E]ntrepreneurship . . . has stained nearly every aspect of public life.

(Jones and Spicer, 2006, p. 179)

\section{INTRODUCTION}

The discourse of entrepreneurship became a pervasive force of social imagination during the 1980s (Cohen and Musson, 2000). Whilst at first used mainly to denote economic phenomena such as growth, wealth creation and prosperity (Drucker, 1985), 'enterprise' and 'entrepreneurship' today are connected to a myriad of non-economic activities, phenomena and values. For instance, entrepreneurship is related to issues as diverse as urban space, street markets, public bureaucracies and society at large. Of late, the discourse of entrepreneurship has been used as an explanatory link between market mechanisms and some of today's most wicked problems such as abject poverty. Examples can be found in an influential UN report entitled Unleashing Entrepreneurship: Making Business Work for the Poor (United Nations, 2004); in it, then Secretary-General Kofi Annan identifies entrepreneurship as the key mechanism for leveraging the private sector in developing nations. Annan thus promotes the view that entrepreneurship will bring market-driven solutions to the sphere of poverty alleviation.

More recently, this 'entrepreneurship-against-poverty' argument has been reiterated through so-called 'bottom of the pyramid' approaches (Brugmann, 2005), which tout the possibility of 'eradicating poverty through profits', to quote the subtitle of Prahalad's (2004) influential The Fortune at the Bottom of the Pyramid. Entrepreneurship's flexibility is further epitomized in how it has come to reshape not only the subjectivity of firm employees (Pongratz and Voß, 2003) but also of artists (Loacker, 
2013), academics (Hatcher, 2001), parents (Eleff and Trethewey, 2006) and clerks (du Gay, 2004) according to the image of the 'enterprising self' (Bröckling, 2002). On the face of it, these tentative examples seem to indicate that 'entrepreneurship today can be almost anything' (Jones and Spicer, 2009, p. 1).

However, although there is no way around conceding that entrepreneurship is a polymorphous signifier without stable meaning, a relatively stable feature of the discourse of enterprise nevertheless is that it endows the various aspects of social, cultural, public and community life to which it gets related with a positive evaluative accent (Weiskopf and Steyaert, 2009). We can hence speak of a purified discourse which effectively hides entrepreneurship's dark sides, predicaments and flaws. It is this purification, however, which ultimately explains why entrepreneurship is univocally regarded as a 'good thing that needs to be wholeheartedly encouraged' (Spicer, 2012, p. 151).

And yet, to translate the orthodoxy of entrepreneurship into a material reality is anything but straightforward. Making entrepreneurship relevant for people's everyday lives presupposes that it discursively affects their habitual way of thinking, acting and talking. That is to say: the discourse of entrepreneurship successfully turns individuals into entrepreneurial subjects only if people get to accept the enterprising self as their 'true nature' (Dey, 2014; Dey and Steyaert, 2014). Interestingly enough, the power of entrepreneurship discourse often seems rather limited as people are reluctant to embrace it uncritically. For instance, Storey, Salaman and Platman (2005), who looked at how the discourse of entrepreneurship has been used to justify changes in the creative industry, were able to show that freelance workers did not endorse the entrepreneurship discourse in a blindfolded manner. Whilst generally very positive about the core features of this discourse, employees evaluated and appropriated entrepreneurship's value according to their own interests; this in turn created 'variety, complexity and in some cases, paradox' (p. 1050). These insights, together with those of similar studies (Cohen and Musson, 2000; Essers and Benschop, 2007; Loacker, 2013), support the conclusion that any inquiry which aims to understand the power of the discourse of entrepreneurship needs to account for how this discourse is received at the local level.

Expanding on these findings, in this chapter I ask how individuals targeted by the discourse of entrepreneurship either identify with or resist it. This question is investigated in the realm of development aid, a context in which discussions of entrepreneurship and business savvy have acquired increasing prominence over the last decades. Rendering non-governmental organizations (NGOs) the focal attention of this chapter seems timely in view of how these organizations have stirred controversy with regard to 
their effectiveness and legitimacy (notably in the realm of development aid), which was followed by suggestions to align them more closely with the principles and values of the private sector. Further, investigating the extent to which the normative desideratum of 'entrepreneurship' is received by development NGO practitioners bears critical currency in the way it exposes possible limits and dangers associated with this discourse (Ainsworth and Hardy, 2008). However, unlike forms of critique which aspire to challenge the discourse of entrepreneurship from a position of exteriority, for example from the transcendental vantage point of moral philosophy, the present critique is conducted from within the coordinates of the entrepreneurship discourse. Framing it as an 'immanent critique' (from Latin immanere, 'to dwell in, remain in'), I subject the discourse of entrepreneurship to critical scrutiny not via universal judgment of 'good' and 'bad' but by attending to the viewpoints of those being addressed or 'hailed' as entrepreneurs.

Thus, the primary objective of the ensuing 'immanent critique' is to disclose the situated agency of development NGO practitioners. Put succinctly, 'situated agency' suggests that even though practitioners might not be able to fully escape the influence of entrepreneurship discourse, they might nevertheless find different ways to resist the discourse (Foucault, 1997a). Therefore I am particularly interested in how practitioners' situated agency gets played out through acts of discursive resistance. My analysis tries to disclose how NGO practitioners use language to displace, negotiate, reconstruct or create alternatives to the discourse of entrepreneurship. Evidently, 'discursive resistance' is a situated and relational activity (Steyaert and Van Looy, 2010) which entails the disruption of the unanimity and authority of the dominant discourse. Involving a refusal to simply endorse entrepreneurship as the object towards which desire must flow, discursive resistance appeals to the transgressive potential of language epitomized in how ordinary conversations and utterances loosen the grip of powerful discourses (Foucault, 1997b).

Against this backdrop, I draw on interviews with practitioners from 12 Swiss non-governmental organizations to probe the extent to which the discourse of entrepreneurship, and its foundational repertoires of 'resultsbased management', 'inputs', 'outcomes', 'indicators' and 'internal and external accounting', are or are not resisted through language. Using the micro-discursive analysis developed by Potter and Wetherell (1987) to gain a clearer understanding of NGO practitioners' interpretations of their everyday (working) life, the study, by remaining attentive to practitioners' own accounts, puts into perspective the sweeping pretention that all development aid NGOs have become subservient to an economic rationality. In this way, the investigation demonstrates how micro-discursive approaches 
permit us to pinpoint language's inherently critical capacity to create socially pertinent meaning that resists dominant discourse.

The chapter is structured as follows. The next section offers a brief elaboration of the NGO sector, including the increasingly important role the discourse of entrepreneurship plays therein. This is followed, second, by a discussion of the micro-discourse analysis' methodology and, third, by the presentation of the findings. Finally, I discuss the results and offer some concluding remarks.

\section{FROM DEVELOPMENT NGOS TO SOCIAL ENTERPRISES}

Developmental non-governmental organizations (development NGOs) are deemed an exciting field of inquiry precisely because their raison d'être has been fundamentally called into question over the past decades. Defenders and proponents usually regard NGOs as prolific actors in the domain of development aid, where they inter alia provide essential services to the most vulnerable people on the planet. However, this only represents the more rose-tinted side of the story. Put briefly, after having been ushered into existence in the post-World War II era, development NGOs have been interrogated with regard to their actual effectiveness and legitimacy. Since the 1960s there has been widespread concern that NGOs were not able, or were insufficiently able, to measure up to the (high) expectations bestowed upon them. While the issues of concern vary, the more widespread critiques are the following: despite the best of intent, development NGOs lack proper understanding of the causes of the problems they seek to solve (Shivji, 2007); they have become too closely aligned with the agendas of those in power and too far removed from the powerless (Banks and Hulme, 2012); NGOs have an appallingly low aid effectiveness record (ISG, 2008); the rise of corporate-NGO partnerships risks compromising the autonomy of the latter (Baur and Schmitz, 2012); and, at worst, this creates a situation where NGOs become co-opted by the hegemonic neoliberal capitalist project (Katz, 2006).

Interestingly enough, though the debate on development NGOs has now been pursued for more than half a century, and harbours different theoretical orientations such as populist thought, neo-Marxism, and antiimperialist and post-colonial theory (Dey, 2007), the critique has increasingly shifted towards the orthodoxy of entrepreneurship. Noteworthy in this regard is William Easterly's (2006) seminal The White Man's Burden which contends that development continues to fail precisely because of a lack of what the author calls 'searchers': people who find ways to get 
things done, who firmly concentrate on the problems to be solved and who are keen to use feedback from those whom they try to serve to fully understand the problem. Playing off searchers against the 'planner' approach, characteristic of the typical centralized and bureaucratic development approach, the implications of Easterly's message are straightforward: given that the approach of the searcher, an obvious analogy for 'entrepreneur', has proven effective in Western democracies, then the NGOs worth thinking of are precisely those that experiment with ideas, that constantly innovate without fear of failure and that rely on competition and consumer feedback to figure out what works.

Easterly is not alone in this assessment. Among others, economist Paul Collier - who is probably best known for his epic treatise on poverty The Bottom Billion (Collier, 2007) - shares many of Easterly's concerns. With over US\$2 trillion spent on development aid since the 1950s with ostensibly little effect, Collier (2013) in a recent speech developed the point that it is the lack of effective organizations that explains why many people earn as little as US\$2 per day. Equating the failure of development aid with the ineffectiveness of the organizations working therein, the solution Collier puts forward hardly comes as a surprise: what development aid organizations need, first and foremost, is a new, more entrepreneurial philosophy. There are a variety of reasons for this, including the belief that incorporating entrepreneurial practices into development endeavours leads to innovation, that is, smarter solutions in poverty alleviation.

Evidently, these ideas go way back to management bestsellers such as Peters and Waterman's (1982) In Search of Excellence which identify the problem of business in their overly bureaucratic and centralized way of organizing. The solution to such inefficiencies is to be found in what du Gay (2004) calls the process of 'enterprising up': individuals, groups and organizations are made 'fit' and 'lean' by instilling economic thinking and by unleashing an entrepreneurial spark. The utility and indeed the necessity of enterprise are implicated in the ever-growing number of development NGOs which are increasingly dependent on a limited donor base. The argument goes that competition over funds literally pushes NGOs towards more entrepreneurial conduct as this allows them to become selfsufficient. Though it remains to be seen whether entrepreneurship will eventually engender the anticipated results, the fact of the matter is that entrepreneurship has already been established as the moral high ground offering development NGOs direction in their quest for effectiveness and survival.

What bears emphasizing here is that entrepreneurship gets related to development NGOs in two different ways. On the one hand, entrepreneurship gets construed as a product or outcome of development NGOs. The 
basic thinking thus is that entrepreneurship has the greatest leverage in eradicating poverty. Micro-credit programmes epitomize, in an emblematic fashion, the hope that the promotion of entrepreneurship in rural areas and deprived urban areas will leverage stagnating economies in Third World countries, a point which is increasingly dismantled as one of the great myths of poverty eradication (Onyuma and Shem, 2005). On the other hand, entrepreneurship gets directly connected with the modus operandi of development NGOs, thus forming a terminus technicus that envisions a new, ostensibly more progressive kind of development organization (if compared with 'traditional' NGOs) whose practice is informed by the logic of the private sector. The blueprint for such a new model of development NGOs is often referred to as 'social entrepreneurship', which is seen as an effective response to the notorious inability of both the market and the state to solve intricate social and ecological problems (Nicholls, 2006).

Social entrepreneurship envisions the ideal development organization as a combination of market efficiency, business savvy and financial selfsufficiency as requisite ingredients for accomplishing social ends (Chand, 2009). While social enterprises retain many of the positive features related to entrepreneurship such as innovation, performance and a heroic outlook (Dey and Steyaert, 2010), it adds to it an almost evangelical belief that social and economic objectives can be combined in such a way that it produces largely positive, win-win situations (Hervieux, Gedajlovic and Turcotte, 2010; for a worthwhile critique compare with Berglund and Schwartz, 2013).

Turning to the Swiss context in which the present study took place, it can be said that social entrepreneurship - quite in contrast to countries such as the United Kingdom and the United States (Nicholls, 2010) - has only just started to infiltrate the public agenda. Though it lags behind most other European countries in terms of government support, signs of change can be found in recent feasibility studies commissioned by the Federal Government and aimed at probing the utility of the concept in the domain of work integration. Also, of late government authorities have started to discuss the value of a specific legal form for social enterprises, and the establishment of capital banks tailored to social enterprises' specific financial needs. The idea of social entrepreneurship has also gained increasing institutional support from the private and voluntary sector.

Social entrepreneurship has received support, in the form of money, knowledge and legitimacy, from representatives of the banking sector such as Credit Suisse, foundations such as Avina and Schwab, a mounting number of globally operating fellowship programmes (such as Ashoka), start-up incubators (such as the Impact Hub), strategy consultancies and law firms, as well as a few academic programmes. Interestingly enough, 
while social entrepreneurship in Switzerland has not experienced the hype that has been seen as in other parts of the world, social entrepreneurship nevertheless appears to be firmly established in practice. This is what is suggested by a recent overview of the state of social entrepreneurship in Switzerland (Gonin and Gachet, 2014) as well as by the results of the Global Enterprise Monitor (GEM) which in 2009 attested that Switzerland had the second highest nascent social entrepreneurship activity (topped only by the USA; Bosma and Levie, 2010). What the report does not reveal, but what is put at centre stage in the ensuing micro-discourse analysis, is the extent to which NGO practitioners emulate the discourse of entrepreneurship which demands attributes like flexibility, risk-taking, perseverance, innovation, and so on, from people who might have hitherto not been deemed, by ruling standards, to be social entrepreneurs.

\section{METHODOLOGY}

\section{Potter and Wetherell's Micro-discourse Analysis}

Informed by an interpretive perspective, the primary aim of the empirical study (Dey, 2007) was to gain an understanding of the power of the discourse of entrepreneurship in development NGOs. Studying discourse's power on the level of how it shapes (or not) individuals in determinate ways, such a focus, as discussed above, opens up an opportunity to gain an embedded understanding of practitioners' situated agency by looking at the contingent choices they make to either endorse or resist the discourse of entrepreneurship. Accordingly, language offers a fitting entry point for studying the extent to which the discourse of entrepreneurship has actually permeated the realm of development aid by affecting practitioners' way of thinking as well as their sense of self.

The analysis of interpretative repertoires (Potter and Wetherell, 1987; Wetherell and Potter, 1988) is particularly pertinent for the task at hand. Of note here is that Potter and Wetherell talk of 'interpretative repertoire' instead of 'discourse' to distinguish their micro-discursive approach from Foucauldian-inspired macro-analysis which conceives of discourse as a regulated system of statements that is relatively independent from specific, local conversations. In concrete terms, informed by ethnomethodology and speech act theory as well as semiology, Potter and Wetherell (1987) put forward a micro-discourse analysis which investigates interpretative repertoires as the linguistic resources which people invoke to constitute their realities and identities. Stressing the constitutive role of language, the analysis of interpretative repertoires takes as its level of analysis the 'range 
of linguistic resources that can be drawn upon and utilized in the course of everyday social interaction' (Edley, 2001, p. 198).

Transposed to the present study, the analysis of interpretative repertoires offers a window for looking at whether and how practitioners adopt and reproduce or resist and transgress the discourse of entrepreneurship. My initial assumption was that the ubiquitous imperatives to become leaner, and more business-like and enterprising would in one way or another be reflected in NGO practitioners' accounts of themselves and their work. Conversely, I was also anticipating the possibility that practitioners within existing limits - would remain situated agents who are able to produce their own socially pertinent meanings. Thus one strength of Potter and Wetherell's analysis of interpretative repertoires is precisely that it offers in-depth insights into how complex, often interwoven processes of affirmation and resistance of the discourse of entrepreneurship are played out at the level of colloquial language. In this way, the analysis of interpretative repertoires captures resistance as a complex language-based process of constant 'adaptation, subversion and reinscription of dominant discourse' (Thomas and Davies, 2005, p. 687).

The question of identity, or what Potter and Wetherell refer to as subject position, is of crucial importance in the present context because the way any given NGO practitioner can think of herself/himself as a person depends upon the interpretative (linguistic) conventions offered to her/him by discourse at a particular point in time. Interpretative repertoires, which offer a basic lexicon of terms for making sense of 'actions and events' (Potter and Wetherell, 1987, p. 187), simultaneously form the corpus of common sense upon which individuals craft a sense of who they are. As Taylor (2005, p.96) mentions, a subject position is 'a temporary identity which is conferred on or taken up by a speaker and which becomes both who she or he is seen to be by others, and the perspective from which she or he sees the world'. Hence, while the discourse of entrepreneurship seeks to transform NGO practitioners on the level of their being, a key purpose of the present inquiry is to shed light on practitioners' discursive identities or, more precisely, the subject positions rendered available to them by specific ways of talking (Edley, 2001).

\section{Description of Sample}

To achieve these aims, I approached around 30 Swiss-based NGOs, asking them whether they would be willing to participate in an interview-based study dealing with the everyday practices and reality of development aid organizations. This resulted in a sample of 12 NGOs. To ensure an adequate amount of variability in practitioners' stories, the investigation 
included a maximum of three participants per organization, which eventually led to a sample of 30 practitioners. All interviews were carried out in the period from early 2003 to late 2004. All organizations were accredited by ZEWO, an independent foundation which provides a seal of approval for Swiss-based voluntary organizations. The organizations' field of activity was international development aid (including relief work, ecological, economic or sustainable development, human rights, migration, or medical or educational support) in countries in the southern hemisphere. A few organizations, particularly the larger ones, also offered their services in Switzerland. The sample mainly consisted of small and medium-sized organizations, with only two organizations employing more than a hundred people, including both paid staff and volunteers. In total, 14 women and 16 men took part in the study. The study included people from different hierarchical levels: office administrators, project administrators and assistants, heads of projects, and volunteers, as well as directors, managers and founders.

\section{Data Collection and Analysis}

Interviews - with one exception - took place at the offices of the respective development NGOs. The interviews were usually initiated by a welcoming remark and a brief outline of the objective of the research project. After that, practitioners were invited to give their account of what they were doing on a day-to-day basis. I tried to step back as much as possible during the interview process, giving maximum space to practitioners' own stories. I became active as an interlocutor during the conversations mainly to keep practitioners' stories going and to make sure that they remained within the broader boundaries of my research project. Interviews lasted between one and two hours, and were guided by a semi-structured interview script. The focus of those questions, which were not shared with practitioners prior to the interviews, was to establish a 'field of visibility' with regard to NGOs' main activities, purposes, crucial challenges and success factors. All interviews were digitally recorded and transcribed.

After a failed attempt at using ATLAS.ti (which proved unhelpful in identifying patterns of meaning between individual interviews), I decided to carry out the analysis on a paper-and-pencil basis, which essentially entailed the following steps. The first analytic step was an iterative reading of the printed transcripts; I marked frequently used words and took notes on recurring topics. This step was descriptive in nature and geared primarily towards getting acquainted with the linguistic corpus (individual concepts) mobilized during the interviews. In the second analytic step I aggregated individual utterances and sentences on the level of 
interpretative repertoires, thus identifying 'relatively internally consistent, bounded language units' (Wetherell and Potter, 1988, p. 171) that constitute a particular understanding of development aid. In the third and related analytic step I further specified the interpretative repertoires with regard to their respective focus (what is the main emphasis of the discursive account?), their protagonist (what are the main actors of the discursive account?) and subject position (what 'location' of the self does the discursive account produce?). From this information, I extracted three interpretative repertoires (described below) which together offer a tentative understanding of the situated agency of NGO practitioners based on the extent to which the interpretative repertoires they summon either affirm or resist its invocation.

\section{RESULTS}

The three interpretative repertoires are shown in Table 6.1. The excerpts used to illustrate the repertoires have been translated from the (Swiss) German transcripts.

\section{Benevolence Repertoire: 'Being Among Equals'}

The first repertoire, called 'benevolence', strongly and at times exclusively associates development aid work with the organization's stated purpose.

Table 6.1 Results from the analysis of interpretative repertoires

\begin{tabular}{|c|c|c|c|}
\hline & $\begin{array}{l}\text { Benevolence } \\
\text { repertoire: 'Being } \\
\text { among equals' }\end{array}$ & $\begin{array}{l}\text { Professionalism } \\
\text { repertoire: 'Doing } \\
\text { the small things } \\
\text { right' }\end{array}$ & $\begin{array}{l}\text { Enterprising } \\
\text { repertoire: 'Enduring } \\
\text { hardship to become } \\
\text { free' }\end{array}$ \\
\hline Core terms & $\begin{array}{l}\text { 'helping', 'supporting' } \\
\text { or 'identification' }\end{array}$ & $\begin{array}{l}\text { 'liability', } \\
\text { 'reasonableness' } \\
\text { or 'sincerity' }\end{array}$ & $\begin{array}{l}\text { 'innovativeness', } \\
\text { 'perseverance' or } \\
\text { 'endurance' }\end{array}$ \\
\hline Addressee & Beneficiaries & Donors & Practitioners \\
\hline $\begin{array}{l}\text { Subject } \\
\text { position }\end{array}$ & $\begin{array}{l}\text { Ideal-type helper } \\
\text { 'supportive, upright } \\
\text { and non-dominant' }\end{array}$ & $\begin{array}{l}\text { Down-to-earth } \\
\text { professional }\end{array}$ & $\begin{array}{l}\text { Autonomous and } \\
\text { risk-taking self-starter }\end{array}$ \\
\hline Emphasis & $\begin{array}{l}\text { Being close to the } \\
\text { field, equality and } \\
\text { pragmatism }\end{array}$ & $\begin{array}{l}\text { Being close to } \\
\text { donors, efficiency } \\
\text { of administrative } \\
\text { practices }\end{array}$ & $\begin{array}{l}\text { Innovativeness, hard } \\
\text { work, being different }\end{array}$ \\
\hline
\end{tabular}


Making frequent use of terms such as 'helping', 'supporting' or 'identification', the benevolence repertoire portrays development NGOs as being chiefly concerned with the well-being of beneficiaries. Practitioners who mobilize the benevolence repertoire use it to delineate the work of development NGOs as 'useful' and 'much needed'. The analysis revealed that the benevolence repertoire's positive evaluative accent largely derives from lauding the importance of human relations:

and that's why it probably worked out in my case ... because the factor 'man' was pivotal, that is, the connection with human fate ... (Interview partner 1)

It must be noted that the category 'man' for the most part encompasses the perspective of beneficiaries, of their relationship with NGO practitioners.

The benevolence repertoire conveys detailed and normative descriptions about how beneficiaries should be treated by practitioners or by the NGO more generally. While the relative emphasis of the different accounts varied considerably, practitioners relying on the benevolence repertoire usually used words such as 'sensitive', 'understanding', 'commitment' and 'empathy' to delineate the proper mindset of NGO practitioners:

We decided to make those children in [name of country] our target group, that's when we began to commit and identify ourselves. (Interview partner 7)

Moreover, the benevolence repertoire uses terms such as 'partnership', 'cooperation' and 'trust' to pinpoint the relational side of development aid work, which is usually depicted as something which requires time, patience and dedication. At the base of the benevolence repertoire is the conviction that beneficiaries can be 'empowered' or 'emancipated'. The support offered by the NGO is mostly seen as temporary, as many accounts stress the principle of 'help for self-help'. The sense of fulfilment associated with development aid work derives from accounts which delineate encounters with beneficiaries as sites of mutual 'learning' and 'growth':

we then went over to [name of region] ... I then realized that we could start an exchange ... meaning that we could learn from each other. (Interview partner 11)

It is hence by acknowledging that the helper and the help recipient both profit from the encounters that the benevolence repertoire gets to defy a hierarchical pedagogy of help.

Though development NGOs are associated with terms such as 'emancipation', it is conspicuous that the benevolence repertoire retains a decisively pragmatic spirit. Instead of using, for instance, political slogans 
to justify their accounts, practitioners using the benevolence repertoire engender a pragmatic vision of development NGOs by providing detailed descriptions of concrete projects. Such elaborate reports of projects on the one hand stress the everydayness of development aid. On the other hand, they discursively legitimate the speaker by purporting that she/he is 'in touch with' or 'close to' the field. Being close with beneficiaries forms a rhetorical trope for justifying that what the organization or practitioners do is grounded in concrete experiences and knowledge.

A last, and important, point which is characteristic of the benevolence repertoire is that it emphasizes 'equality' between NGO practitioners and beneficiaries: 'for instance . . . our approach in development work is based on the premise that one is among equals ...' (Interview partner 23). The notion of 'equality' and 'equals' is employed to delineate the work of development NGOs as non-oppressive. Furthermore, it is by positioning normative ideals such as equality and sameness as a proxy for justice that the benevolence repertoire works to rule out possibilities of control, patronage or unequal relations of power at large.

Concerning the subject position implied in the benevolence repertoire, it follows from the analysis that the ideal-type helper is constructed as supportive, upright and non-dominant. The point to note here is that the benevolence repertoire does not engender images of self-sacrifice, which has been identified elsewhere as an inherent part of social work (Dempsey and Sanders, 2010). Though stressing activities such as 'supporting' or 'helping', the helper is usually not construed as a person who subordinates her/his own interests to those of beneficiaries. Instead, working with beneficiaries is portrayed as an activity that is equally fulfilling for the helper and the help recipient. Helpers are assumed to understand that 'equality' forms a higher good which has to be constantly worked on and protected. Helpers thus simultaneously treat 'equality' as a pre-condition of successful development aid work and as an end in itself. It is this latter aspect which renders the helper a subject for whom the journey (and not necessarily the journey's outcome) forms the reward. Though a genuine interest in beneficiaries is one of their key characteristics, helpers are not naïve idealists chasing high-flying dreams. Instead of 'thinking big' and envisioning development aid as necessarily leading to landslide changes, the helper is someone who remains in the 'here and now', thus focusing on the challenges associated with NGOs' mundane practices.

\section{Professionalism Repertoire: 'Doing the Small Things Right'}

Practitioners who enact the professionalism repertoire get to emphasize the crucial importance of donors and the role of administrative practices. 
At base, the professionalism repertoire construes development NGOs as being largely about 'good management'. However, professionalism exceeds the sort of 'entrepreneurial new wave management' discussed by du Gay (2000). In concrete terms, the professionalism repertoire is underpinned by terms such as 'liability', 'reasonableness', and 'sincerity' in praising the ethos of bureaucracy. With development NGOs conceived of as a bundle of well-coordinated yet divisible administrative practices, the yardstick of good management is 'doing one's job right', that is, focusing on one's immediate task without necessarily taking into account the 'big picture':

the only thing which he [the director] asks me about is when he wants to make payments and that's when I can say yes or no . . . other than that I don't influence the decisions of the organization ... (Interview partner 14)

On the face of it, stressing the view that the success of development NGOs is a matter of clearly defined roles and responsibilities, the professionalism repertoire gets to connect practitioners' liabilities to their immediate realm of specialization. That is, responsibilities and duties are defined and thus limited by the role, position or function a given individual holds within the organization. While this might be taken as an indication that professionals are people who are disinterested and who have no virtues, it should be noted that the professionalism repertoire does in fact speak about values. Yet, in contrast to the benevolence repertoire which is based on a strong moral foundation (read 'equality'), the professionalism repertoire mainly envisions values in relation to efficiency. In doing so, it promotes the idea that good things become possible only if each and every member of the organization fulfils her/his personal duties in the best possible way, that is, efficiently.

What is of particular interest here is that efficiency functions as a dividing practice that distinguishes between admissible and inadmissible development NGOs, legitimate development NGOs obviously being those who are efficient: 'what distinguishes us from others is our efficiency ...' (Interview partner 9). On the other hand, a sense of legitimacy is also built by associating efficiency with the broader responsibility of development NGOs. Hence, legitimate development NGOs are not just those who are efficient but also those which measure their efficiency and which transparently communicate their performance to their donors (read accountability). Essentially, where the benevolence repertoire positions 'being close to beneficiaries' as both a moral imperative and a source of fulfilment, the professionalism repertoire construes the ethos of development NGOs in relation to 'being close to donors'. Relations with donors are thus positioned in a business-case logic, meaning that practices of 
transparency and accountability are evaluated according to whether or not they improve the NGO's reputation and, ultimately, whether they secure donors' financial support.

The professionalism repertoire's subject position construes NGO practitioners as down-to-earth professionals who pursue their work in a calm and logical manner. Professionals are construed as prudent problemsolvers who rely on their expertise and knowledge. Practitioners who make use of this repertoire clearly do not radiate the sense of excitement one finds in the subject position of the ideal-type helper. Yet, this does not mean that professionals are not committed to their work. Rather, professionals convey a work ethos that construes responsibility in relation with expertise and efficiency. As a result, professionals act responsibly if they efficiently carry out their work in their respective field of specialization, thus explicitly not assuming responsibility beyond their designated institutional role. Professionals are deeply moral subjects to the extent that they accept that the success of development NGOs depends on the contribution of each and every individual and, consequently, that people must at all times remain reliable, transparent and efficient.

\section{Enterprising Repertoire: 'Enduring Hardship to Become Free'}

The third repertoire, coined 'enterprising', is clearly less palpable in practitioners' accounts. In fact, I only identified the enterprising repertoire in accounts uttered by founders of development NGOs. In contrast to the benevolence repertoire which focuses on beneficiaries, or the professionalism repertoire which focuses on donors, the enterprising repertoire puts the perspective of NGO practitioners on centre stage. Apart from construing development aid work as being based on individual attributes such as 'innovativeness', 'perseverance' or 'endurance', the enterprising repertoire also stresses relational practices such as 'collaborating' and 'dialogue': 'it would not have been possible to start [name of the organization] without ... without leading discussions ... without people with whom I was able to have discussions and whom I could ask things' (Interview partner 19). This clearly contradicts the idea that the competition over scarce financial resources has delimited the likelihood of dialogue and cooperation among development NGOs.

A further point to be mentioned is that at first sight the enterprising repertoire seems to create a good fit with the benevolence repertoire as both employ attributes such as 'involvement', 'commitment' and 'passion'. However, there are subtleties which clearly distinguish the two repertoires. In contrast to the benevolence repertoire which relates the affective qualities of development aid work with the beneficiaries and, by doing so, 
depicts them as ends in themselves, the enterprising repertoire uses those qualities in a more instrumental way. That is, practitioners who enact the enterprising repertoire suggest that affective qualities such as passion are necessary to endure the 'hardship' related with development aid work.

The notion of 'hardship' is thus endowed with two distinct meanings. On the one hand, individual 'hardship' is exemplified through the daily hassles and obstacles of everyday life, and thus denoted as an inevitable 'side effect' in the pursuit of the organization's mission. On the other hand, and more poetically, 'hardship' gets conceived of as a rite of passage in the quest towards being free: while development aid work is conceived of as offering individuals an autonomous and free style of existence, it is through 'hardship' that the person's transformation materializes: 'of course we earn less than others but that doesn't bother me much ... all that counts today is that I'm free to do what I please' (Interview partner 2).

A last point worth noting concerns the enterprising repertoire's emphasis on 'being small' and 'being innovative'. Juxtaposing small and big organizations, the enterprising repertoire gets to defy bureaucratic organizations based on the argument that they are not innovative. Innovativeness is thus located within an economic logic as small organizations are delineated as compensating for their relative lack of financial resources by being innovative: 'there are a lot of good ... organizations which do not need that much money because they largely depend on people's innovativeness ...' (Interview partner 30).

A striking aspect of the enterprising repertoire is that it produces its subject position (read the entrepreneur) without actually using the term 'entrepreneur' or 'enterprising'. Though clearly surprising, this is not a general paradox because the enterprising repertoire does produce the subject position of the entrepreneur based on attributes which are seen as typical of entrepreneurs. That is, interweaving attributes such as 'selfmade', 'persevering' and 'risk-taking', the entrepreneur is discursively produced as someone who approaches work in an enterprising fashion. At this juncture, I should mention that attributes such as 'risk-taking', which is commonly seen as a characteristic aspect of the entrepreneur's innate personality, are discursively created as contingent behaviours. More precisely, the analysis showed that 'risk-taking' is construed as a behaviour which is made necessary due to the NGO sector's 'open' or 'insecure' prospects. Construing 'risk-taking' as a necessary consequence in the face of an uncertain environment rather than an innate quality of the person clearly challenges the idea of possessive individualism which sees the social entrepreneur as a free agent who owns herself/himself completely.

Furthermore, the entrepreneur is not delineated as a larger-thanlife figure but as a hard-working, at times creative, person and, most 
importantly, as someone who wants to be autonomous and free. At heart, the sense of enjoyment associated with the prospect of becoming an entrepreneur is intimately conjoined with the desire to lead a more autonomous life. Though representing entrepreneurs as people who 'go against the grain', the enterprising repertoire does not invoke the image of the isolated maverick which is commonplace in popular renditions of entrepreneurship. Instead, it produces a logic which sees 'being different' as the entrepreneur's primary drive to become free in the first place.

\section{DISCUSSION}

The starting point of this contribution has been that the discourse of entrepreneurship has permeated the field of development aid while increasingly demanding that NGO practitioners should think and act more like their entrepreneurial counterparts from the business world. A key insight that can be gleaned from the analysis is that although NGO practitioners might have increasingly become the object of a kind of knowledge that seeks to render development aid more enterprising, they are not determined by it, since they retain the possibility of producing their own pertinent meanings (Fiske, 1989).

But saying that the discourse of entrepreneurship is not deterministic or 'muscular' (Alvesson and Kärreman, 2000) because practitioners are variously able to resist it is not to say that NGO practitioners are autonomous in deciding who they want to be. Hence, rather than standing in a position exterior to the discourse of entrepreneurship, our results sensitize us about the situated agency of practitioners by highlighting how they try to resist the ubiquitous call to enterprise up by immersing themselves in complex struggles over meaning (Putnam, Grant, Michelson and Cutcher, 2005).

To deepen our understanding of the power of the discourse of entrepreneurship, including its very limit, one should note that participants in my study rarely resisted the discourse of entrepreneurship head-on, as they did in the Parkinson and Howorth (2008) study where reservations against and dislike of social entrepreneurship formed the core of practitioners' talk. Perceiving the term 'entrepreneurship' as too closely associated with the world of business, practitioners in that study framed the concept in negative terms, inter alia describing it 'as 'dirty', 'ruthless', 'ogres', 'exploiting the black economy', 'wealth and empire building' and 'treating people as second class' (Parkinson and Howorth, 2008, pp. 300-301). From my own analysis, such oppositional forms of discursive resistance are most likely if participants are explicitly asked for their opinion on a contested subject (Dey and Teasdale, 2013). If instead participants were simply invited to 
offer an account of their everyday work, and thus given the opportunity to sketch their experiences in their own words, this mostly resulted in more subtle forms of resistance which were less based on overt antagonism than on either the introduction of alternative repertoires or on the appropriation of the discourse of entrepreneurship.

The first form of resistance occurs in the benevolence repertoire, which is reminiscent of traditional notions of development aid that stress issues such as equality, non-dominance and support. While the benevolence repertoire embodies precisely the kind of rationality which the discourse of entrepreneurship portrays as outdated (since it is ineffective), we can understand that enacting this repertoire forms a cunning attempt at re-inheriting the kind of values and subject positions which have 'gone missing' in the wake of the 'enterprising up' of development aid. As speakers establish a connection with the aborted past of development aid by touching on the importance of values such as equality, togetherness and unconditionality, they in turn get to disrupt the coherence and authority of the discourse of entrepreneurship by demonstrating that the entrepreneurial revolution of development aid is anything but inevitable.

Similar things can be said about the professionalism repertoire. Although its focus on accountability and efficiency seems to put the professionalism repertoire squarely on par with the discourse of entrepreneurship, the professionalism repertoire nevertheless resists the anti-bureaucratic ethos which characterizes the discourse of entrepreneurship. Resistance becomes palpable in how the professionalism repertoire reconciles the virtues of bureaucratic organizing with the idea of effective development aid, thus placing on centre stage a form of organizing which, according to the discourse of entrepreneurship, has long since lost its right to exist. Just like the benevolence repertoire, the professionalism repertoire makes the case for the continuing importance of the past. Invigorating the virtues of bureaucracy entails a political thrust in the way it prevents the discourse of entrepreneurship from fully encroaching upon the meaning of development aid. Both the benevolence and professionalism repertoires support the conclusion that the ostensible marginalization of the social being proclaimed by critics of the discourse of entrepreneurship might be overestimated as practitioners keep resisting its power by invoking alternative repertoires (Frogett and Chamberlayne, 2004; Parkinson and Howorth, 2008; Seanor and Baines, 2013).

The second form of resistance is based on appropriating the meaning of the discourse of entrepreneurship and can be observed most clearly in the enterprising repertoire. A pervasive feature of the enterprising repertoire is that it entails intermittent moments of reproduction and resistance (Thomas and Davies, 2005). Indeed, a cursory glance at the enterprising 
repertoire seems to suggest that practitioners' talk is firmly co-opted by the discourse of entrepreneurship, as it reproduces issues such as innovativeness, perseverance and an anti-bureaucratic stance, said to be essential characteristics of entrepreneurship.

However, such an appraisal is misleading to the extent that it fails to acknowledge that the enterprising repertoire is not a mimetic reproduction of the discourse of entrepreneurship, because it includes various, if elusive, modifications. As already mentioned, the enterprising repertoire lacks the sort of pomp and utopianism radiated by the discourse of entrepreneurship. Further, an important aberration of the enterprising repertoire is that it values being small, whereas the discourse of entrepreneurship emphasizes the need to 'go big', to scale up and hence to reach as many beneficiaries as possible (Alvord, Brown and Letts, 2004).

Probably an even more noteworthy sign of appropriation can be detected in the reasons the enterprising repertoire offers as to why people get involved in an entrepreneurial career or venture. Unlike the discourse of entrepreneurship which conceives of entrepreneurship as an innate attribute of the individual which is triggered by the desire to offer solutions to difficult problems, in the enterprising repertoire the individual's desire to have a lasting effect on the world is of secondary importance. Rather than trying to save the world on a shoestring, as it were, the enterprising repertoire tells a story of personal transformation where the individual embarks on a journey which leaves him/her changed. Development aid thus represents the context in which a transformation of the self is deemed possible. This is important not only because it counteracts the spectacular undertone of the discourse of entrepreneurship (Dempsey and Sanders, 2010) but also because it shows that in the enterprising repertoire the primary purpose of becoming an entrepreneur is to become free. The entrepreneur in this repertoire is an individual who 'sacrifices' a normal life for a lifestyle which offers freedom and individual self-fulfilment.

Cursory though these illustrations have been, they alert us to how NGO practitioners, as they use language to give an account of themselves and their work, manage to resist the discourse of entrepreneurship in important ways. Both forms of discursive resistance just discussed stand in obvious contrast to the etymological meaning of 'resistance' (from Latin resistere 'to make a stand against') as oppositional practice. The analysis of practitioners' interpretative repertoires has confirmed that resistance entails a strong creative element, as they constantly make choices between competing meanings while accounting for their choices by negotiating 'their own understanding within their own particular worlds' (Cohen and Musson, 2000, p. 44). By implication, the force of both forms of resistance results from how they play with the possibilities offered by the ambivalence 
entailed by the discourse of entrepreneurship. Such a view evidently contradicts interpretations which see the discourse of entrepreneurship as capable of completely positioning individuals in terms of their being and, by implication, making them governable (Carmel and Harlock, 2008).

This said, I must immediately reiterate that the sort of resistance my micro-discursive analysis was able to disclose entails a situated agency, not an absolute one. NGO practitioners' choices are not entirely free (read anything goes) as they are restricted to choosing among or appropriating discourses which are already socially legitimated (Dart, 2004). Therefore, although it may be true that NGO practitioners cannot remove themselves completely from the influences of the discourse of entrepreneurship, what they can do is appropriate existing discourses or introduce alternative ones in a way that develops creative opportunities for venturing beyond the dominant discourse.

\section{CONCLUSION}

A crucial contention I have made in this chapter is that any understanding of the power of the discourse of entrepreneurship would be incomplete without taking into account the perspective of those who are usually seen as mere objects of this discourse (Parkinson and Howorth, 2008). Exemplified through the usage of Potter and Wetherell's methodology, this analysis of practitioners' language use has helped us rebuild a sense of agency back into our understanding of the discourse of entrepreneurship (Jones and Spicer, 2009) by hinting at how people resist it in largely creative ways.

Micro-discourse analytic methods, such as the one developed by Potter and Wetherell, offer important means for enhancing our understanding of the subtlety and creativity of resistance, and thus render visible how resistance unfolds around struggles around meaning (Putnam et al., 2005). Importantly, micro-discourse analyses derive their force as an instrument of critical analysis from unveiling aspects of social reality which are marginalized or rendered unimaginable by dominant discourse. Bringing into play that which is 'excluded, ignored or repressed' in the dominant discourse of entrepreneurship (Froggett and Chamberlayne, 2004, p. 71), micro-discourse analysis can operate as a means of immanent critique whose primary function is to probe the disjuncture between what is strategically defined and what might become possible but is yet only a transient possibility embodied in the local use of language. As immanent critique, micro-discourse analysis is able to root out precisely those alternatives 'which are often in conflict with the wave of euphoria and optimism that 
is driving current theoretical development in the field of social enterprise and entrepreneurship' (Bull, 2008, p. 272). Where the critical function of micro-discourse analysis is to denaturalize dominant discourses by dissolving their apparent authority and inevitability into contingent knowledge, the attribute 'immanent' further indicates that no erudition is needed to clarify what is best for the people concerned. Indeed, what micro-discourse analysis brings to the forefront is that the potential for resistance and, by implication, change, is always already part of people's everyday existence.

To conclude, there is no reason to romanticize micro-discourse analysis since one never knows whether the immanent potential to which such analyses point will ever prevail or whether people's resistance will ultimately remain without broader effect. Given that we cannot know what will happen, I believe that micro-discourse analysis merits further attention as it offers the means for investigating when and where resistance is disruptive, that is, when and where local discursive resistance of the kind discussed in this chapter will translate into transversal, more coordinated and orchestrated forms of resistance (Marchart, 2003). Hence, will the discourse of entrepreneurship ever make development aid subservient to economic and managerial thinking? We do not know. What we do know is that micro-discourse analysis can help us address this question by offering the tools to document the minutiae of the power of the discourse of entrepreneurship, including ways this power might be subverted and changed over time.

\section{REFERENCES}

Ainsworth, Susanne and Cynthia Hardy (2008), 'The enterprising self: An unsuitable job for an older worker', Organization, 15 (3), 389-405.

Alvesson, Mats and Dan Kärreman (2000), 'Varieties of discourse: On the study of organizations through discourse analysis', Human Relations, 53 (9), $1125-1149$.

Alvord, Sarah H., L. David Brown and Christine W. Letts (2004), 'Social entrepreneurship and societal transformation: An exploratory study', The Journal of Applied Behavioral Science, 40 (3), 260-282.

Banks, Nicola and David Hulme (2012), 'The role of NGOs and civil society in development and poverty reduction', accessed 7 September 2013 at www.bwpi. manchester.ac.uk/resources/Working-Papers/bwpi-wp-17112.pdf.

Baur, Dorothea and Hans Peter Schmitz (2012), 'Corporations and NGOs: When accountability leads to co-optation', Journal of Business Ethics, 106 (1), 9-21.

Berglund, Karin and Brigitta Schwartz (2013), 'Holding on to the anomaly of social entrepreneurship: Dilemmas in starting up and running a fair-trade enterprise', Journal of Social Entrepreneurship, 4 (3), 237-255.

Bosma, Niels and Jonathan Levie (2010), 'Global entrepreneurship monitor: 2009 
Executive Report', accessed 23 July 2013 at www.gemconsortium.org/docs/ download/666.

Bröckling, Ulrich (2002), 'Das unternehmerische Selbst und seine Geschlechter. Gender-Konstruktionen in Erfolgsratgebern', Leviathan, 48, 175-194.

Brugmann, Jeb (2005), 'All paths lead to BOP', Alliance, 10, 1 September.

Bull, Michael (2008), 'Challenging tensions: Critical, theoretical and empirical perspectives on social enterprise', International Journal of Entrepreneurial Behaviour \& Research, 14 (5), 268-275.

Carmel, Emma and Jenny Harlock (2008), 'Instituting the "third sector" as a governable terrain: Partnership, performance and procurement in the UK', Policy and Politics, 36 (2), 155-171.

Chand, Vijaya Sherry (2009), 'Beyond nongovernmental development action into social entrepreneurship', Journal of Entrepreneurship, 18 (2), 139-166.

Cohen, Laurie and Gill Musson (2000), 'Entrepreneurial identities: Reflections from two case studies', Organization, 7 (1), 31-48.

Collier, Paul (2007), The Bottom Billion: Why the Poorest Countries are Failing and What can be Done About It, Oxford: Oxford University Press.

Collier, Paul (2013), 'Social enterprise and aid: Pump-priming the missing effective organizations', Keynote presented at Locating Social Entrepreneurship in the Global South: Innovations in Development Aid Conference, Washington, DC, 12 March.

Dart, Raymond (2004), 'The legitimacy of social enterprise', Non-profit Management \& Leadership, 14 (4), 411-424.

Dempsey, Sarah E. and Matthew L. Sanders (2010), 'Meaningful work? Nonprofit marketisation and work/life balance in popular autobiographies of social entrepreneurship', Organization, 17 (4), 437-459.

Dey, Pascal (2007), On the Name of social Entrepreneurship: Business School Teaching, Research, and Development Aid, unpublished doctoral dissertation, Basel, Switzerland: University of Basel.

Dey, Pascal (2014), "Governing the social through "social entrepreneurship": A Foucauldian view of the "art of governing in advanced liberalism", in Heather Douglas and Suzanne Grant (eds), Social Innovation and Social Entrepreneurship: Context and Theories, Melbourne: Tilde University Press, pp. 55-72.

Dey, Pascal and Chris Steyaert (2010), 'The politics of narrating social entrepreneurship', Journal of Enterprising Communities, 4 (1), 85-108.

Dey, Pascal and Chris Steyaert (2014), 'Rethinking the space of ethics in social entrepreneurship: Power, subjectivity, and practices of concrete freedom', Journal of Business Ethics, published online 19 November.

Dey, Pascal and Simon Teasdale (2013), "Social enterprise" and dis/identification: The politics of identity work in the UK third sector', Administrative Theory and Praxis, 35 (2), 249-271.

Drucker, Peter (1985), Innovation and Entrepreneurship, London: Sage.

Easterly, William (2006), The White Man's Burden: Why the West's Efforts to Aid the Rest have done so much Ill and so little Good, New York: Penguin Press.

Edley, Nigel (2001), 'Analysing masculinity: Interpretative repertoires, ideological dilemmas and subject positions', in Margaret Wetherell, Stephanie Taylor and Simeon J. Yates (eds), Discourse as Data: A Guide for Analysis, London: Open University Press \& Sage, pp. 189-228.

Eleff, Leanne Ralya and Angela Trethewey (2006), 'The enterprising parent: A 
critical examination of parenting, consumption and identity', Journal of the Association for Research on Mothering, 8 (1-2), 242-251.

Essers, Caroline and Yvonne Benschop (2007), 'Enterprising identities: Female entrepreneurs of Moroccan or Turkish origin in the Netherlands', Organization Studies, 28 (1), 49-69.

Fiske, John (1989), Reading the Popular, New York: Routledge.

Froggett, Lynn and Prue Chamberlayne (2004), 'Narratives of social enterprise: From biography to practice and policy critique', Qualitative Social Work, 3 (1), 61-77.

Foucault, Michel (1997a), 'Sex, power and the politics of identity', in Paul Rabinow (ed.), Ethics: Subjectivity and Truth, New York: The New York Press, pp. 163-173.

Foucault, Michel (1997b), 'What is critique?', in Paul Rabinow (ed.), The Essential Works of Michel Foucault, Vol. 1: Ethics, Subjectivity and Truth, New York: The New Press, pp. 263-278.

du Gay, Paul (2000), In Praise of Bureaucracy: Weber, Organization, Ethics, London: Sage.

du Gay, Paul (2004), 'Against "Enterprise" (but not against "enterprise", for that would make no sense)', Organization, 11 (1), 37-57.

Gonin, Michaël and Nicolas Gachet (2014), 'Social enterprise models in Switzerland: An overview of existing streams, practices, and institutional structures', working paper presented at the ICSEM project, Lausanne, Switzerland, July.

Hatcher, Caroline (2001), 'The enterprising academic: Transforming the master', Electronic Journal of Radical Organizational Theory, accessed 2 August 2015 at www.mngt.waikato.ac.nz/ejrot/. . ./Hatcher.pdf.

Hervieux, Chantal, Eric Gedajlovic and Marie-France B. Turcotte (2010), 'The legitimization of social entrepreneurship', Journal of Enterprising Communities, 4 (1), 37-67.

ISG (2008), CSO parallel process to the Ghana High Level Forum Network, accessed 16 March 2006 at http://www.whiteband.org/resources/issues/aid/ index_html/the-aid-effectivenessdebate/a-critical-approach-to-the-aideffectiveness-agenda.

Jones, Campbell and André Spicer (2006), 'Outline of a genealogy of the value of the entrepreneur', in Guido Erreygers and Geert Jacobs (eds), Language, Communication and the Economy, Amsterdam: John Benjamins Publishing, pp. 179-197.

Jones, Campbell and André Spicer (2009), Unmasking the Entrepreneur, Cheltenham, UK and Northampton, MA, USA: Edward Elgar Publishing.

Katz, Hagai (2006), 'Gramsci, hegemony, and global civil society networks', Voluntas, 17 (4), 333-348.

Loacker, Bernadette (2013), "Becoming “culturpreneur": How the "neoliberal regime of truth" affects and redefines artistic subject positions', Culture and Organization, 19 (2), 124-145.

Marchart, Oliver (2003), 'Bridging in micro-macro-gap: Is there such a thing as post-subcultural politics?', in David Muggleton and Rupert Weinzierl (eds), The Post-subcultures Reader, New York: Berg, pp. 83-97.

Nicholls, Alex (2006), Social Entrepreneurship: New Paradigms of Sustainable Social Change, Oxford: Oxford University Press.

Nicholls, Alex (2010), 'The legitimacy of social entrepreneurship: Reflexive 
isomorphism in a pre-paradigmatic field', Entrepreneurship Theory and Practice, 34 (4), 611-633.

Onyuma, Samuel O. and Alfred O. Shem (2005), 'Myths of microfinance as a panacea for poverty eradication and women empowerment', Savings and Development, 29 (2), 199-222.

Parkinson, Caroline and Carole Howorth (2008), 'The language of social entrepreneurs', Entrepreneurship \& Regional Development, 20 (3), 285-309.

Peters, Tom and Robert H. Waterman (1982), In Search of Excellence: Lessons from America's Best-Run Companies, New York: Harper \& Row.

Pongratz, Hans J. and Günter G. Voß (2003), Arbeitskraftunternehmer: Erwerbsorientierungen in entgrenzten Arbeitsformen, Berlin: edition sigma.

Potter, Jonathan and Margaret Wetherell (1987), Discourse and Social Psychology: Beyond Attitudes and Behaviour, London: Sage.

Prahalad, C.K. (2004), The Fortune at the Bottom of the Pyramid: Eradicating Poverty through Profits, Upper Saddle River, NJ: The Free Press.

Putnam, Linda L., David Grant, Grant Michelson and Leanne Cutcher (2005), 'Discourse and resistance: Targets, practices, and consequences', Management Communication Quarterly, 19 (1), 5-18.

Seanor, Pam and Sue Baines (2013), 'Narratives of transition from social to enterprise: You can't get there from here!', Journal of Entrepreneurial Behavior \& Research, 19 (3), 324-343.

Shivji, Issa G. (2007), Silences in NGO Discourse: The Role and Future of NGOs in Africa, Oxford: Fahamu.

Spicer, André (2012), 'Critical theories of entrepreneurship', in Kevin Mole and Monder Ram (eds), Perspectives in Entrepreneurship: A Critical Approach, Basingstoke: Palgrave Macmillan, pp. 149-160.

Steyaert, Chris and Bart Van Looy (eds) (2010), Relational Practices, Participative Organizing. Advanced Series in Management Vol. 7, Bingley: Emerald.

Storey, John, Graeme Salaman and Kerry Platman (2005), 'Living with enterprise in an enterprise economy: Freelance and contract workers in the media', Human Relations, 58 (8), 1033-1054.

Taylor, Stephanie (2005), 'Narrative as construction and discursive resource', Narrative Inquiry, 16 (1), 94-102.

Thomas, Robyn and Annette Davies (2005), 'Theorizing the micro-politics of resistance: New public management and managerial identities in the UK public services', Organization Studies, 26 (5), 683-706.

United Nations (2004), Unleashing entrepreneurship: Making business work for the poor, accessed 2 July 2006 at web.undp.org/cpsd/documents/report/english/ fullreport.pdf.

Weiskopf, Richard and Chris Steyaert (2009), 'Metamorphoses in entrepreneurship studies: Towards an affirmative politics of entrepreneuring', in Daniel Hjorth and Chris Steyaert (eds), The Politics and Aesthetics of Entrepreneurship. A Fourth Movements in Entrepreneurship Book, Cheltenham, UK and Northampton, MA, USA: Edward Elgar Publishing, pp. 183-201.

Wetherell, Margaret and Jonathan Potter (1988), 'Discourse analysis and the identification of interpretative repertoires', in Charles Antaki (ed.), Analysing Everyday Explanation: A Casebook of Methods, Newbury Park, CA: Sage, pp. $168-183$. 